\title{
Enzyme immunoassay compared with cell culture and immunofluorescence for detecting genital chlamydia
}

\author{
G MUMTAZ, GL RIDGWAY, A NAYAGAM, * JD ORIEL* The Departments of Microbiology \\ and ${ }^{*}$ Genitourinary Medicine, University College Hospital, London
}

SUMMARY A novel enzyme immunoassay test (Pharmacia EIA) was evaluated against cell culture for the detection of chlamydial genital infection. Specimens were obtained from 525 patients ( 257 men and 268 women). Sensitivity, specificity, predictive value of positive (PVP) and predictive value of negative (PVN) for the new test were, respectively, 83.6, 98.5, 94.4 and $95 \cdot 1 \%$ for men and $86,97 \cdot 2$, $\mathbf{8 7 . 8}$ and $96.8 \%$ for women. Discrepancies were further evaluated by repeating the EIA, and by direct immunofluorescence on the EIA transport buffer. The sensitivity, specificity, PVP and PVN of the EIA against the combination of cell culture and direct immunofluorescence were, respectively 85.9, 100,100 , and $95 \cdot 5 \%$ for men, and $90 \cdot 5,98 \cdot 1,92 \cdot 3$ and $97 \cdot 7 \%$ for women. Overall agreement between the EIA and the combination of cell culture and direct immunofluorescence was $97 \%$. The Pharmacia EIA is rapid and simple to perform and does not require elaborate equipment.

Non-cultural techniques for the diagnosis of oculogenital chlamydial infection are now widely used. Such techniques are largely based on either immunofluorescence microscopy, or on enzyme immunoassay (EIA). None of these techniques is wholly reliable and discrepancies may occur. ${ }^{.}$Even cell culture does not detect all active chlamydial infections. It is therefore necessary to ensure that new tests are evaluated in such a way as to determine as accurately as possible whether the results agree with those of the best techniques currently available. We describe the evaluation of a novel EIA against a standard cell culture technique. Discrepancies were further analysed using a direct immunofluorescence antigen detection technique, applied to the transport buffer for the EIA test.

\section{Material and methods}

All the patients attended the department of genitourinary medicine at this hospital. Endourethral swabs from 257 men with non-gonococcal urethritis (NGU) and cervical swabs from 268 women who were contacts of men with NGU were studied. Patients who had received antibiotics during the previous four weeks were excluded. Endourethral swabs were obtained by inserting a cotton-wool tipped wire swab 4-5 cm into the urethra; cervical swabs were taken with a cotton-wool tipped plastic swab rotated in the

Accepted for publication 12 December 1988 cervical canal after first wiping the cervix with gauze.

Two swabs were collected from each patient. One was placed in EIA transport buffer and the other into 2-sucrose phosphate chlamydial transport medium. The order of collection was determined by reference to a random number table. ${ }^{2}$

\section{CHLAMYDIAL CULTURE}

Specimens for culture were held at $+4^{\circ} \mathrm{C}$, and processed within 24 hours of receipt. Culture for Chlamydia trachomatis was performed using cycloheximide treated McCoy cells. ${ }^{3}$ Two cell culture tubes were inoculated per sample. The coverslip from one tube was examined after 48-72 hours' incubation, using an immunofluorescence culture confirmation test (Syva Co., Pal Alto, California, USA). The contents of the second tube were passaged on to a fresh cell sheet and examined by immunofluorescence after incubation for a further $48-72$ hours.

\section{EIA}

Samples for EIA were collected into storage buffer supplied by Pharmacia Diagnostics $\mathrm{AB}$ and processed within 48 hours of collection if stored at $4^{\circ} \mathrm{C}$, or within two weeks if stored at $-20^{\circ} \mathrm{C}$, as recommended in the manufacturer's instructions.

Samples were diluted in $0.5 \mathrm{ml}$ of diluent buffer and incubated at room temperature for 10-15 minutes. Samples were then agitated at room temperature for one minute and the swab expressed and discarded. The samples were boiled for 10 minutes, cooled, and then tested as follows: 
1 Clinical specimen or controls $(100 \mu \mathrm{l})$ was added to the wells of a microtitre strip (Pharmacia Diagnostics AB, Uppsala, Sweden). The strip was incubated for 30 minutes at $37^{\circ} \mathrm{C}$, to allow chlamydial antigen (lipopolysaccharide) if present, to adsorb to the well surface.

2 Enzyme (alkaline phosphatase) $(50 \mu \mathrm{l})$ labelled monoclonal antibody was added to each well, and incubated for 45 minutes at $37^{\circ} \mathrm{C}$.

3 The wells were washed four times with the washing solution provided and $100 \mu \mathrm{l}$ of the substrate (paranitrophenol phosphate) added. The strip was incubated for one hour at $37^{\circ} \mathrm{C}$. A yellow colour (paranitrophenol) was produced in wells containing chlamydial antigen.

4 The reaction was stopped by the addition of $50 \mu \mathrm{l}$ of $2.5 \mathrm{M} \mathrm{NaOH}$. The intensity of colour (optical density) developed was measured at $405 \mathrm{~nm}$ in a spectrophotometer and compared with a fixed cut off value, as recommended by the manufacturers.

\section{DIRECT IMMUNOFLUORESCENCE}

The remainder of the EIA buffer, which had been stored at $-20^{\circ} \mathrm{C}$, was thawed at room temperature and shaken vigorously for 10 seconds. Buffer $(0.1 \mathrm{ml})$ was placed on a Teflon coated slide and air dried. The preparation was fixed in acetone for $\mathbf{3 0}$ minutes and then stained with an immunofluorescent anti- $C$ trachomatis monoclonal antibody (Syva Microtrak) according to the manufacturer's instructions. Specimens were examined by immunofluorescence microscopy for typical chlamydial elementary bodies.

\section{Results}

Cell culture showed that the prevalence of $C$ trachomatis was $23.7 \%$ (61 of 257 ) for men and $18.6 \%$ (50 of 268) for women. Comparative figures for EIA alone were, respectively, $21 \%$ (54 of 257 ) for men and $18.2 \%$ (49 of 267) for women. There were 13 discrepant results among men and 13 among women (table 1). Thus the sensitivity, specificity, PVP and PVN were, respectively, $83.6,98.5,94.4$ and $95.1 \%$ for men, and $86,97 \cdot 2,87 \cdot 8$ and $96.8 \%$ for women. Further analysis of the 26 discrepant results by repeating the EIA and by direct immunofluorescence on the EIA transport buffer yielded the following findings.

\section{MEN}

Nine specimens positive by cell culture were repeatedly EIA negative. Four of these specimens yielded isolates only after passage, suggesting the presence of a low concentration of antigen. These specimens were recorded as false negative by EIA. One EIA negative, culture positive specimen was EIA positive on a second test, and therefore recorded as a true positive.
Table 1 Positive and negative results obtained by enzyme immunoassay and cell culture of specimens from 257 men and 268 women

\begin{tabular}{|c|c|c|c|c|}
\hline \multirow{3}{*}{$\begin{array}{l}\text { Enzyme } \\
\text { immunoassay }\end{array}$} & \multicolumn{4}{|c|}{ Cell culture } \\
\hline & \multicolumn{2}{|c|}{ Positive } & \multicolumn{2}{|c|}{ Negative } \\
\hline & Men & Women & Men & Women \\
\hline $\begin{array}{l}\text { Positive } \\
\text { Negative }\end{array}$ & $\begin{array}{l}51 \\
10\end{array}$ & $\begin{array}{r}43 \\
7\end{array}$ & $\begin{array}{r}3 \\
193\end{array}$ & $\begin{array}{r}6 \\
212\end{array}$ \\
\hline
\end{tabular}

The remaining three specimens were EIA positive, cell culture negative, and all three were positive by direct immunofluorescence. These specimens are therefore recorded as true positives (cell culture failures). Table 2 shows the results corrected for the EIA second test and the direct immunofluorescence results. Sensitivity, specificity, PVP and PVN of the test using the corrected results were $85.9,100,100$ and $95.5 \%$, respectively.

\section{WOMEN}

Passage of cell culture did not yield more isolates than the primary isolation. Five specimens were repeatedly EIA negative and cell culture positive. These results were recorded as false negative by EIA. Of the six EIA positive, cell culture negative specimens, three were positive and three were negative by direct immunofluorescence. Three were therefore recorded as true positives (cell culture failure), and three as false positive by EIA. Two specimens initially EIA negative were positive on repeated examination and had yielded isolates in cell culture. They were recorded as true positives. Finally, one EIA negative, cell culture negative specimen was. EIA positive on repeat (repeated because of high negative optical density), and was reclassified as a false positive EIA. Recalculation of these results (table 2) yielded figures of 90.5 , $98 \cdot 1,92 \cdot 3$ and $\mathbf{9 7 . 7 \%}$ for sensitivity, specificity, PVP and PVN, respectively.

There was no correlation between discrepant results and time or temperature at which the EIA specimen was stored.

Table 2 Positive and negative results obtained by enzyme immunoassay and cell culture and/or direct immunofluorescence from specimens of 257 men and 268 women

\begin{tabular}{|c|c|c|c|c|}
\hline \multirow{3}{*}{$\begin{array}{l}\text { Enzyme } \\
\text { immunoassay }\end{array}$} & \multicolumn{4}{|c|}{ Cell culture/immunofluorescence } \\
\hline & \multicolumn{2}{|c|}{ Positive } & \multicolumn{2}{|c|}{ Negative } \\
\hline & Men & Women & Men & Women \\
\hline $\begin{array}{l}\text { Positive } \\
\text { Negative }\end{array}$ & $\begin{array}{r}55 \\
9\end{array}$ & $\begin{array}{r}48 \\
5\end{array}$ & $\begin{array}{r}0 \\
193\end{array}$ & $\begin{array}{r}4 \\
211\end{array}$ \\
\hline
\end{tabular}




\section{Discussion}

EIA techniques offer potential advantages over direct immunofluorescence techniques because they are objective and easy to automate. There has been some controversy, however, over the sensitivity and specificity of EIA compared with direct immunofluorescence techniques. Jones et al ${ }^{4}$ and ourselves ${ }^{2}$ have previously reported EIA studies yielding sensitivities and specificities of 85 and $98 \%$ and 92.5 and $97 \%$, respectively, against single cycle cell culture, results which compare favourably with direct immunofluorescence methods. ${ }^{56}$ Others have been less enthusiastic.' All would agree that there is room for improvement in EIA tests.

Most previous studies have compared EIA with single cycle cell culture. There is little doubt that cell culture fails to detect all positive specimens so it is vital to ensure that optimal culture conditions are used. To this end we used cycloheximide treated McCoy cells, stained by immunofluorescent monoclonal antibody, and passage of cultures, in line with the recommendations of Schachter. ${ }^{8}$ We also examined the EIA buffer from discrepant specimens using direct immunofluorescence. We detected a further four specimens on passage of cultures. All were negative by EIA and direct immunofluorescence, suggesting low concentrations of antigen in the original specimens. Direct immunofluorescence yielded a further six positive results over cell culture, giving a sensivity of $95 \%$ for cell culture (111 of 117 positive results) compared with the total number of positive isolates. The six specimens positive by direct immunofluorescence were all positive by EIA. Only four specimens could be designated as false positive by EIA, one of which was only positive on retest for a high negative first reading.

We did not test all EIA samples by direct immunofluorescence, and therefore the possibility exists that direct immunofluorescence positive, EIA, and culture negative results were not detected. It should be noted, however, that all specimens positive by direct immunofluorescence were also positive by EIA.

The population studied was at high risk for chlamydial infection. Schachter has drawn attention to the need to consider the prevalence of a pathogen in the population when assessing non-cultural detection methods. ${ }^{8}$ The PVP result will be reduced in low risk groups compared with high risk groups; in contrast, the PVN result will be increased. The results for the PVP and PVN obtained in this study for the Pharmacia EIA compare favourably with cell culture and direct immunofluorescence, but caution is still required when interpreting positive results in low risk populations until further work is done to evaluate the test in these groups.

The combined results for sensitivity, specificity, PVP and PVN in this study for EIA against cell culture and direct immunofluorescence were 88, 99, 96 and $97 \%$, respectively. Agreement between the new test and the combination of cell culture and direct immunofluorescence was $\mathbf{9 7 \%}$. These results are very encouraging. The test is rapid, simple to perform, and does not require elaborate equipment. It should prove a useful and reliable non-cultural technique for the detection of chlamydial antigen from urogenital sites.

\section{References}

1 Ridgway GL. The laboratory diagnosis of chlamydial infection. In: Oriel JD, Ridgway GL, Schachter J, Taylor-Robinson D, Ward M, eds. Chlamydial infection. London: Cambridge University Press, 1986;539-49.

2 Mumtaz G, Mellars BJ, Ridgway GL, Oriel JD. Enzyme immunoassay for the detection of $\mathrm{C}$ trachomatis antigen in urethral and endocervical swabs. J Clin Pathol 1985;38:740-2.

3 Ripa KT, Mårdh PA. Cultivation of $\mathrm{C}$ trachomatis in cycloheximide treated McCoy cells. J Clin Microbiol 1977;6:328-33.

4 Jones MF, Smith TF, Houglam AJ, Herrmann JE. Detection of $\mathrm{C}$ trachomatis in genital specimens by the Chlamydiazyme test. J Clin Microbiol 1984;20:465-7.

5 Tam MR, Stamm WE, Handsfield HH, et al. Culture independent diagnosis of $C$ trachomatis using monoclonal antibodies. $N$ Engl J Med 1984;310:1146-50.

6 Thomas BJ, Evans RT, Hawkins DA, Taylor-Robinson D. Sensitivity of detecting $\mathbf{C}$ trachomatis elementary bodies in smears by use of a fluoroscein labelled monoclonal antibody: comparison with conventional chlamydial isolation. $J$ Clin Pathol 1984;37:812-6.

7 Taylor-Robinson D, Thomas BJ, Osborn MF. Evaluation of enzyme immunoassay (Chlamydiazyme) for detecting $\mathbf{C}$ trachomatis in genital specimens. J Clin Microbiol 1987;40:194-9.

8 Schachter J. Rapid diagnosis of sexually transmitted diseasesspeed has a price. Diagn Microbiol Infect Dis 1986;4:185-9.

Requests for reprints to: Mrs G Mumtaz, Department of Microbiology, University College Hospital, Grafton Way, London WC1E 6AU, England. 